Journal of Al-Azhar University Engineering Sector

Vol.16, No. 61, October 2021, 1100-1110

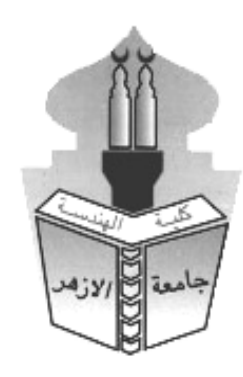

\title{
COMPARISON OF DIFFERENT METHODS FOR PRODUCING BIODIESEL FROM EGYPTIAN JATROPHA SEEDS AND LOCAL WASTE COOKING OIL
}

\author{
H.M. Abu Hashish ${ }^{1} *$, Said M. A. Ibrahim ${ }^{2}$, K.A. Abed ${ }^{1}$ \\ ${ }^{1}$ Mechanical Engineering Department, Engineering Research Division, National Research Centre, \\ Giza, Egypt. \\ ${ }^{2}$ Mechanical Engineering Department, Faculty of Engineering, Al-Azhar University, Cairo, Egypt. \\ *Corresponding Author E-mail: HM.AbuHashish@nrc.sci.eg
}

\section{ABSTRACT}

The increasing demand and consumption growth rates of diesel fuel together with environmental concerns directed attention to the use of non-edible oils such as jatropha or waste cooking oil (WCO) as alternative biofuels in diesel engines. Extraction methods of jatropha seeds and waste cooking oil collection have effects on the physical and chemical properties of the produced bio-oil and biodiesel; these properties have effects on engine performance and emissions. Oil characteristics such as viscosity, density, calorific value, flash point, and Cetane number were considered.

The aim of this paper is to compare bio-oil or biodiesel which are produced by extraction methods from Egyptian jatropha seeds and WCO. The extraction method of Jatropha oil is by using a screw press, and that from WCO is by a chemical method. A screw press was designed, manufactured, and tested on the laboratory scale, to produce oil at extraction temperature of $100^{\circ} \mathrm{C}$ and screw speed of $60 \mathrm{rpm}$. The effect of temperature on oil density and viscosity for the extraction processes were investigated. Correlations were deduced which relate viscosities and densities with oil temperature for the studied bio-oil and biodiesel. The raw material used for producing the bio-oil affect the fatty acid composition. The production temperature also has effects on the viscosity and density of the extracted oil by the different processes.

Free fatty acid (FFA) compositions are measured to be 2.7 and $4.596 \%$ for jatropha bio-oil and WCO bio-oil, respectively. The density of waste cooking bio-oil is $916 \mathrm{~kg} / \mathrm{m} 3$ which is better than that produced from jatropha oil. The kinematic Viscosity of jatropha biodiesel being 1.4 is better than that of WCO oil. The flash point of waste cooking oil is better than all different oils, on the other hand, the Cetane number of waste cooking oil is better as compared to other oils. The heating value of waste cooking oil is better than different types of oil. Therefore, the waste cooking oil is the best to use, otherwise use preheated jatropha oil.

KEYWORDS: Jatropha seeds, Yield, Screw press, Waste cooking oil (WCO), Biodiesel, Bio-oil. 


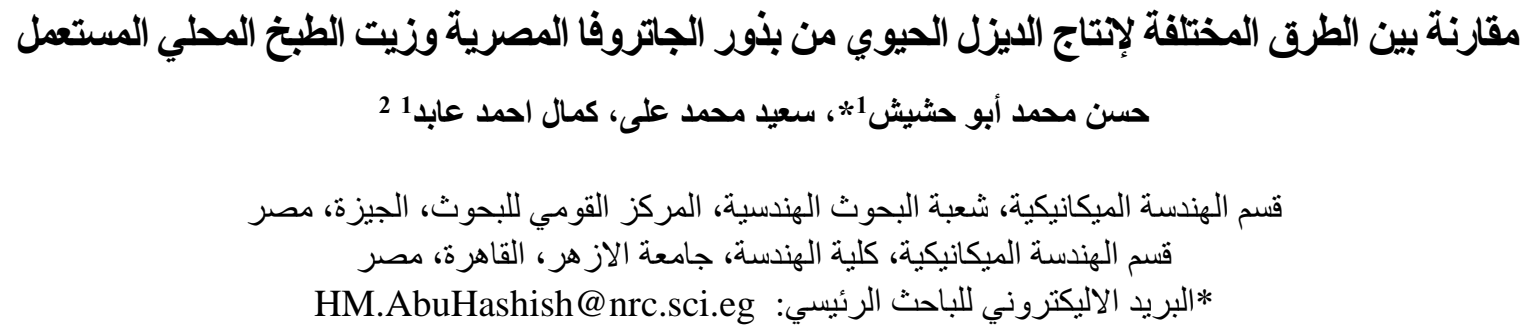

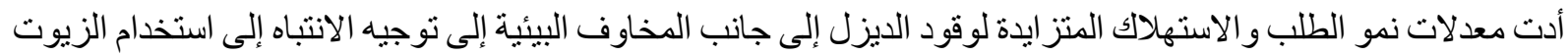

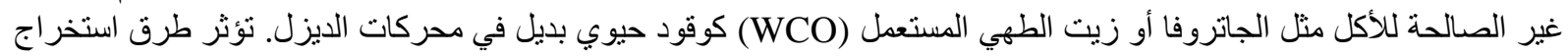

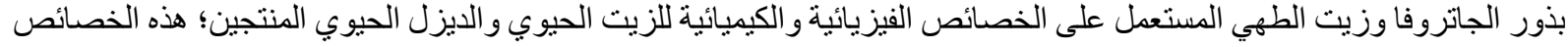

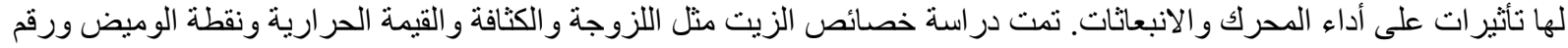
السيتان.

الهدف من هذا البحث هو مقارنة الزيت الحيوي أو وقود الديزل الحيوي الذي ينم إنتاجه من خلال طرق الاستخر اج من بذور الجاتروفا

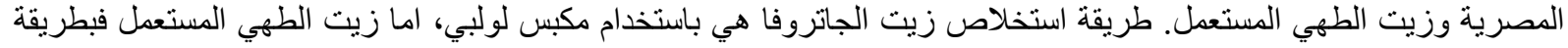

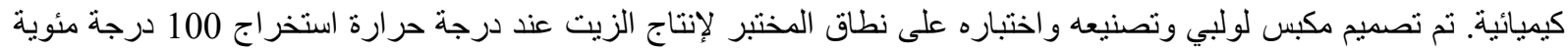

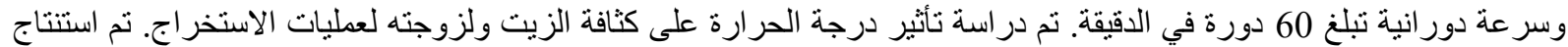

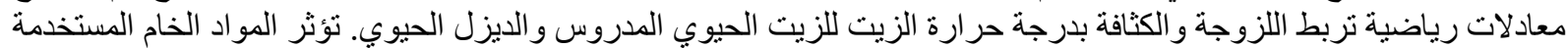

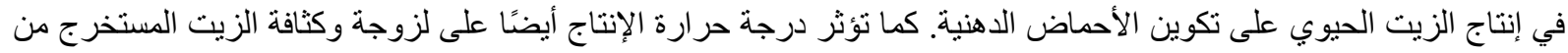

خلال العمليات المختلفة. تم قياس تركيب الأحماض الدهنية الحرة (FFA) بنسبة 2.7 و4.596٪ لزيت الجاتروفا الحيوي ووزيت الطهي المستعمل، على التو الي.

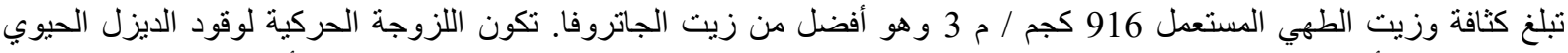

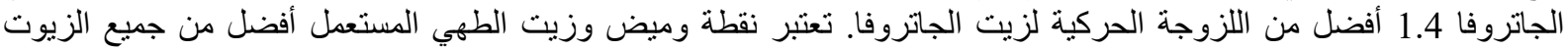

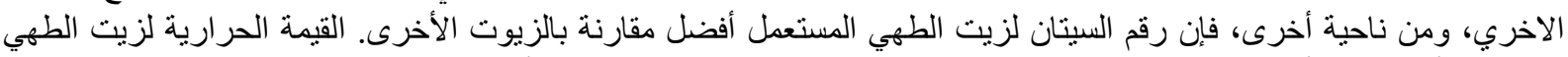

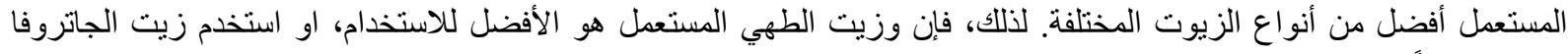
المسخن مسبقًا. الكلمات المفتاحية: بذور الجاتروفا، العائد الامثل، مكبس لولبي، زيت الطهي المستعمل (WCO)، وقود الديزل الحيوي، الزيت الحيوي.

\section{INTRODUCTION}

The continuous increase in global energy demand has been followed by an increase in the rate of growth in spent fossil fuel consumption. Burning fossil fuels is the main cause of harmful emissions and global warming. An effective partial solution to fossil fuel emissions is the use of alternative biofuels [1].

Edible vegetable oils are very expensive, so researchers are working on ways to produce biodiesel from non-edible vegetable oils such as jatropha seeds and waste cooking oil. Jatropha trees can be grown in deserts and irrigated with wastewater. Jatropha oil can be extracted from the seeds by chemical methods or mechanical presses [2]. Jatropha oil is inedible before detoxification, which makes it the best choice to use as an alternative source of biodiesel. Jatropha is a multi-purpose shrub belonging to the Euphorbia group, which grows best in the subtropical parts of Africa and Asia. Jatropha oil can be converted into biodiesel using the transesterification process or use oil directly in diesel engines or oil burners with oil pre-treatment $[2,3]$. Ancient extraction methods to extract oil from seeds had used both manual and simple methods; these are at present the least useful. Jatropha oil can be extracted mechanically by pressing the seeds, chemically, and enzymatically [4-6]. At present, Jatropha seeds are used to extract oil by expellers .It is somewhat important to use a screw press to produce a higher yield with acceptable physicochemical properties of the oil [7,8].

A fixed screw press was used to extract oil from jatropha seeds with a cylindrical barrel and a helical screw on a conical shaft supported by bearings with a shaft [9]. The hopper feeds the screw with seeds to be pressed into the cylindrical housing and the cake comes out from the other end, and the oil comes out through small holes in the bottom of the barrel [9]. Jatropha oil extraction by screw press is more efficient in producing higher yield than other known methods. There are minimum extraction 
temperatures to reduce the percentage of free fatty acids in the extracted oil. The extraction temperature of 75 to $100{ }^{\circ} \mathrm{C}$ and the screw speed of 20 to $60 \mathrm{rpm}$ gave the maximum output of the jatropha extract. These conditions also reduce the motor power and torque of the screw driver [1].

Producing biodiesel from waste cooking oil has economic benefits, as its cost is the lowest among renewable and conventional fuels [10]. Since plants and vegetable oils and animal fats are renewable sources of biomass, biodiesel represents a mostly closed cycle of carbon dioxide (about 78\%) as it is derived from renewable sources of biomass [11]. Edible vegetable oils make up over $95 \%$ of world biodiesel production [12]. References [13,14] stated that the use of edible oils in biodiesel production could lead to some negative impacts in developing countries, such as malnutrition and higher food prices. Where the prices of refined virgin oils are generally very high, commercial production of biodiesel fuel is therefore impracticable [15]. The highly important issue in biodiesel production is the cost of the raw material which could account for up to 75 percent of the total cost of production [16]. These results in prices of biodiesel 1.5 times higher than those of fossil diesel [17].

So, the use of HORECA (hotels , restaurants and catering) WCO as raw material is one way to cut costs, since these oils are 2-3 times cheaper than vegetable oils from crops or trees [18]. Biodiesel benefits include safe, reliable, displaces diesel fuel, reduces global warming, and reduces gas pollution like air toxics. Biodiesel drawbacks include high cost relative to hydrocarbon diesel, a small rise in emissions of nitrogen oxides, and long-term storage changes in fuel properties [19].

The main objective of the current research is to produce jatropha oil from jatropha seeds while increasing the extraction productivity to allow commercial production. A screw press was designed, manufactured, and tested in our laboratory for producing biodiesel from jatropha nuts. WCO was used to produce biodiesel. The biodiesel produced from these two sources are compared. The effect of the extraction process on free fatty acid composition and properties of the bio-oil was studied. Physicochemical properties of jatropha oil and biodiesel are compared to WCO and biodiesel.

\section{MATERIALS AND METHODS}

Egyptian jatropha is grown at high temperatures in dry weather in Upper Egypt. Jatropha fruits are peeled for using the seeds to extract oil. The screw press method was adopted in this paper to produce bio-oil from Jatropha seeds. Waste cooking oil (WCO) sample was collected from a public restaurant in Cairo, Egypt.

\subsection{Screw Press Method}

The screw press is a continuous extraction method, and it gives a high yield. It was designed and tested by the authors to produce a large amount of oil jatropha from seeds of up to $20 \%$. [1]. This screw press has a base and casing. Casing has a hopper to feed jatropha seeds to press in rotating screw.

Oil is collected from holes down the casing. The electric motor has gearbox to reduce rotational speed from 1420 to $142 \mathrm{rpm}$ by using reduction ratio 1:10, this motor used to drive the screw press. The screw speed is controlled by inverter Jatropha seeds were preheated by Heaters out the casing, temperature control by using temperature digital thermostat from room temperature to $300^{\circ} \mathrm{C}$. The maximum oil yield was achieved to obtain oil with the proper properties at $60 \mathrm{rpm}$ rotational speed and $100{ }^{\circ} \mathrm{C}$ preheating temperature [1]. The screw press schematic diagram and its parts are presented in Figure 1 [1]. 


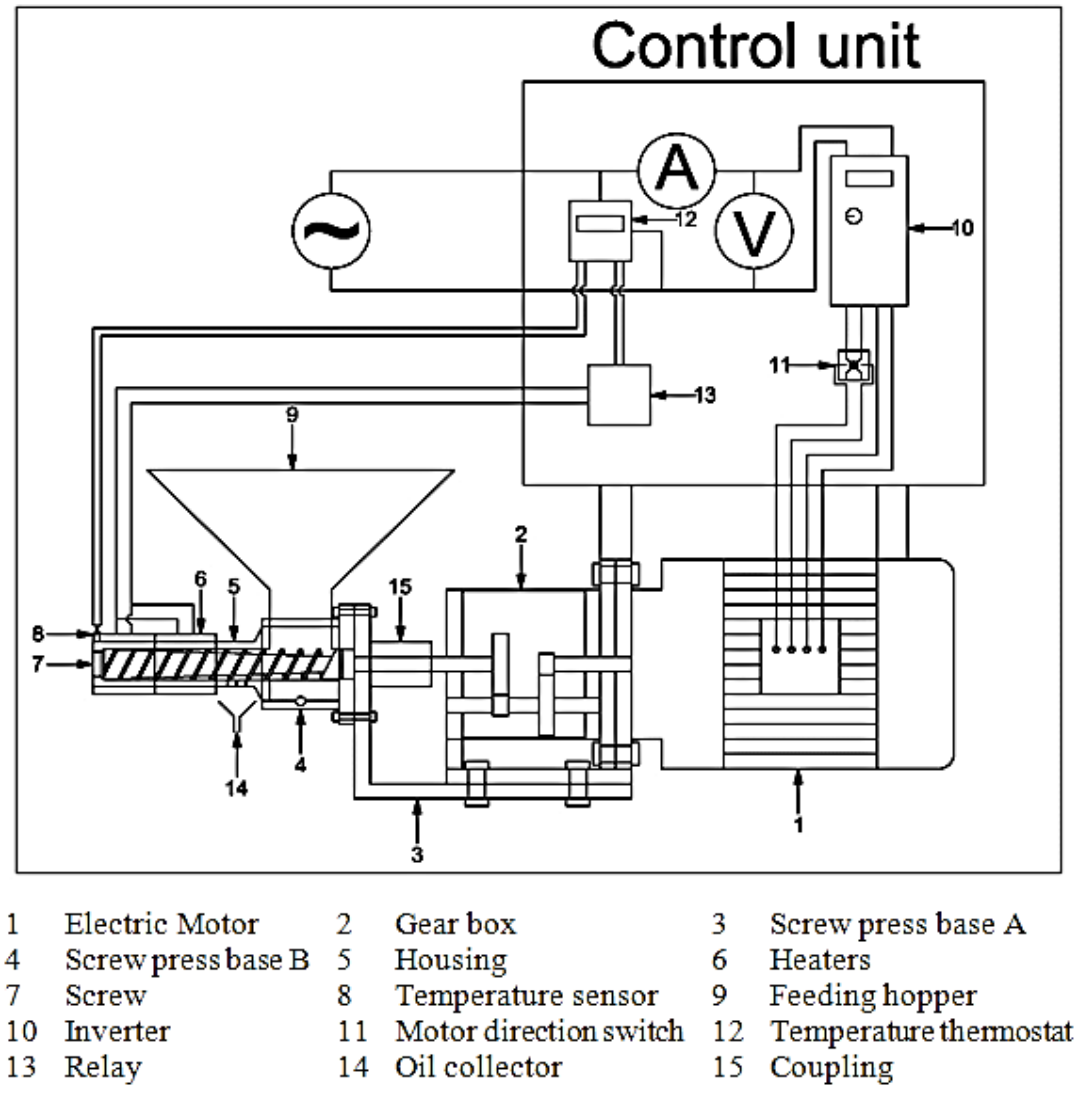

Fig. 1: The screw press schematic diagram and its parts

\subsection{Biodiesel Production Process}

Jatropha biodiesel was produced by esterification followed by transesterification processes to jatropha oil. WCO biodiesel was produced by transesterification processes of the waste cooking oil. Methanol and sulfuric acid as a catalyst blended with jatropha oil between one to three hours at a temperature of $80^{\circ} \mathrm{C}$, it's called the esterification process. Methanol and sodium hydroxide as a catalyst mixed to oil (jatropha - WCO) by the ratio of 20\% Methanol and 0.5\%:1\% sodium hydroxide. The solution is poured into a separate funnel for up to 12 hours. The biodiesel will float at the top while the denser glycerin will be at the bottom of the funnel. Glycerol looks very dark compared to the yellow biodiesel [20, 21].

\subsection{Gas Chromatography Method}

Gas Chromatography (GC) technique used for measuring oil sample fatty acid composition by mixtures separation based on their boiling point. The methylation process is used to prepare oil samples for GC $[3,22,23]$.

\section{RESULTS AND DISCUSSIONS}

\subsection{Free Fatty Acid}

The oil processing extraction method or its cooking way affect the oil color, thus the oil quality as indicated in Fig. 2. The extraction temperatures affect the physicochemical properties. The oil will oxidize according to the applied temperature. Oil darker color resulted from higher extraction temperature or a long time on high cooking temperature. The oil darker color is caused by oxidation during the process (extraction or cooking). WCO bio-oil is found to be darker than jatropha oil extracted by screw processes. Oil extraction methods or cooking regime change both the color of oil and its quality. 
Lovibond number is a scale used widely as a comparative method between oil colors $[1,3,22]$ and is presented in Fig. 2. Table 1 depicts jatropha oil and WCO fatty acid percentages and their Lovibond numbers. Jatropha oil extracted by screw press has Lovibond No. 4 and a minimum FFA of $2.7 \%$ because its color is light. WCO has Lovibond No. 10 and a maximum FFA of $4.596 \%$ because its color is darker. Titration was used to calculate oil FFA percentage. $\mathrm{NaOH}$ solution prepared by mixing four grams of $\mathrm{NaOH}$ in one liter of distilled water. $10 \mathrm{ml}$ of pure isopropyl alcohol are blended with one $\mathrm{ml}$ of jatropha oil. The mixture preheated slowly under stirring until the oil is completely dissolved in alcohol. The end point will appear by use Phenolphthalein indicator. Phenolphthalein is added to the mixture in two drops. $\mathrm{NaOH}$ solution is added drop by drop to the oil alcohol phenolphthalein solution, with stirring until the appearance of a pink solution for 10 seconds. FFA percentage calculation from titration from these equations $[24,25]$.

$\mathrm{FFA} \%=\frac{28.2 \times \mathrm{V} \times \mathrm{n}}{\mathrm{w}}$

Where,

$$
\begin{aligned}
& \mathrm{V}=\text { Titration solution volume in } \mathrm{ml}, \\
& \mathrm{n}=\mathrm{NaOH} \text { solution normality }(\mathrm{n}=0.025), \text { and } \\
& \mathrm{w}=\text { Oil sample weight in grams }(1 \mathrm{ml}=0.92 \mathrm{~g}) .
\end{aligned}
$$

Thus,

FFA $\%=0.766 \mathrm{~V}$

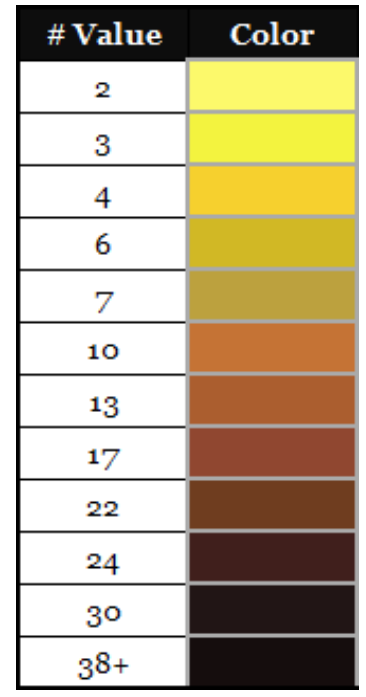

Fig. 2: Lovibond scale for oil extraction or cooking color

Table 1: Jatropha oil and WCO fatty acid percentage and their Lovibond Nos

\begin{tabular}{cccc}
\hline No. & Extraction process & FFA, \% & Lovibond No. \\
\hline 1 & Jatropha oil extracted by screw press (JSP) & 2.7 & 4 \\
\cline { 2 - 4 } 2 & $\begin{array}{c}\text { Oil extracted from local waste cooking oil } \\
\text { (WCO) }\end{array}$ & 4.596 & 10 \\
\hline
\end{tabular}

\subsection{Gas Chromatography Analysis}

The retention indices of the separated fatty acids methyl esters components were calculated using fatty acids methyl esters standards (C4-C22), (Sigma Aldrich Co.) as references. There are three main types of fatty acids that can be presented in a triglyceride which is saturated $(\mathrm{Cn}: 0)$, monounsaturated $(\mathrm{Cn}: 1)$ 
and polyunsaturated with two or three double bonds $(\mathrm{Cn}: 2,3)$. Various vegetable oils are potential feed stocks to produce a fatty acid methyl ester or biodiesel, but the quality of the fuel will be affected by the oil composition. The vegetable oil should have lower saturation and lower Poly unsaturation.

The major fatty acids in jatropha oil are oleic, linoleic, palmitic, and stearic fatty acids, and those for waste cooking oil are palmitic and oleic. Jatropha bio-oil can be classified as linoleic-palmitic oil compared to waste cooking oil bio-oil which is classified as Oleic-palmitic oil. Jatropha oil has higher linoleic fatty acid and WCO oil has higher oleic fatty acid as shown in Table 2 and Fig. 3.

Table 2: Jatropha oil and WCO oil fatty acid composition

\begin{tabular}{cccc}
\hline No. & Fatty acid & WCO & Jatropha oil \\
\hline 1 & Palmitic (16:0) \% & 31.00 & 25.26 \\
\hline 2 & Stearic $(18: 0) \%$ & - & 2.11 \\
\hline 3 & Oleic $(18: 1) \%$ & 69.00 & 17.09 \\
\hline 4 & Linoleic $(18: 2) \%$ & - & 48.15 \\
\hline
\end{tabular}

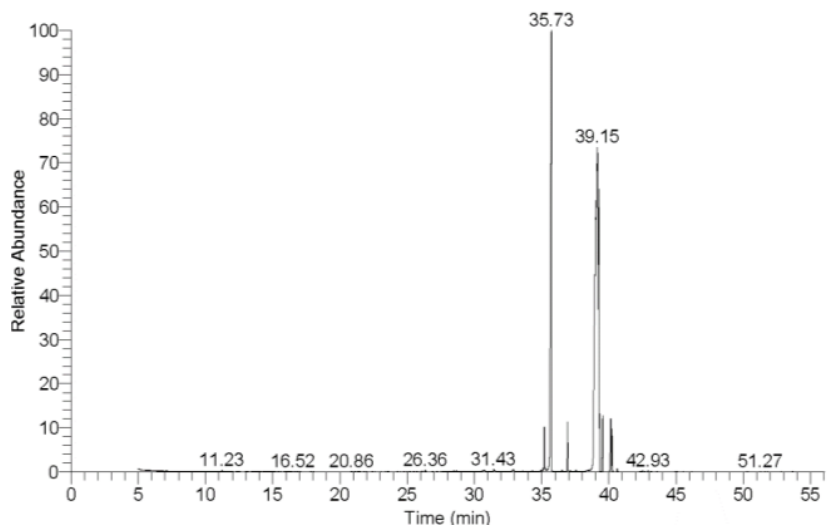

(a): Jatropha oil extraction by Screw press

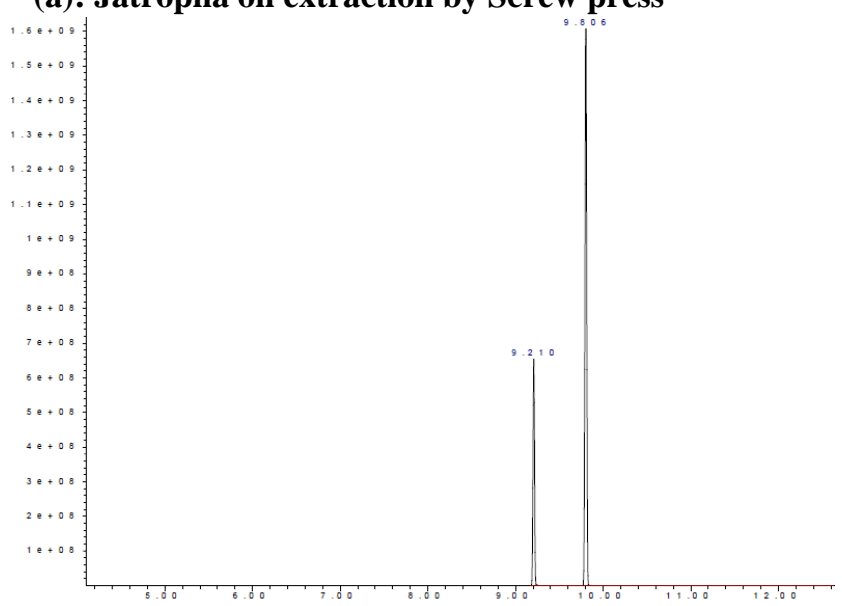

(b): Waste cooking oil (WCO) bio-oil

Fig. 3: Fatty acid compositions by GC for oils

\subsection{Effect Of Temperature On Oil Density}

Figure 4 exhibits the variations in densities for different temperatures of oil and biodiesel. The results indicate that oil temperatures have significant effect on the density of the extracted oils. The measured values of densities by test method ASTM D4052 at the same temperature of $20^{\circ} \mathrm{C}$ for fossil diesel, jatropha oil, jatropha biodiesel, waste cooking oil, WCO biodiesel are 829, 913, 876, 916, and 865.01 $\mathrm{kg} / \mathrm{m}^{3}$, respectively. The densities of oils decrease with increase in temperature. The density is inversely 
proportional to the oil temperature as a linear relationship as obtained from the measured results. The density can be correlated as a linear relationship with oil temperature for the extraction processes as shown in Table 3. Density correlations at different temperatures can predict and calculate densities for oil and biodiesel.

Table 3: Temperature and density correlations for oil and biodiesel

\begin{tabular}{ccc}
\hline No. & Type & Density Equations \\
\hline 1 & Jatropha oil & $\rho=-0.576 \mathrm{~T}+923.73$ \\
\hline 2 & Biodiesel of Jatropha oil & $\rho=-0.6072 \mathrm{~T}+885.84$ \\
\hline 3 & Waste cooking oil & $\rho=-0.615 \mathrm{~T}+926.5$ \\
\hline 4 & Biodiesel of waste cooking oil & $\rho=-0.5705 \mathrm{~T}+877.27$ \\
\hline
\end{tabular}

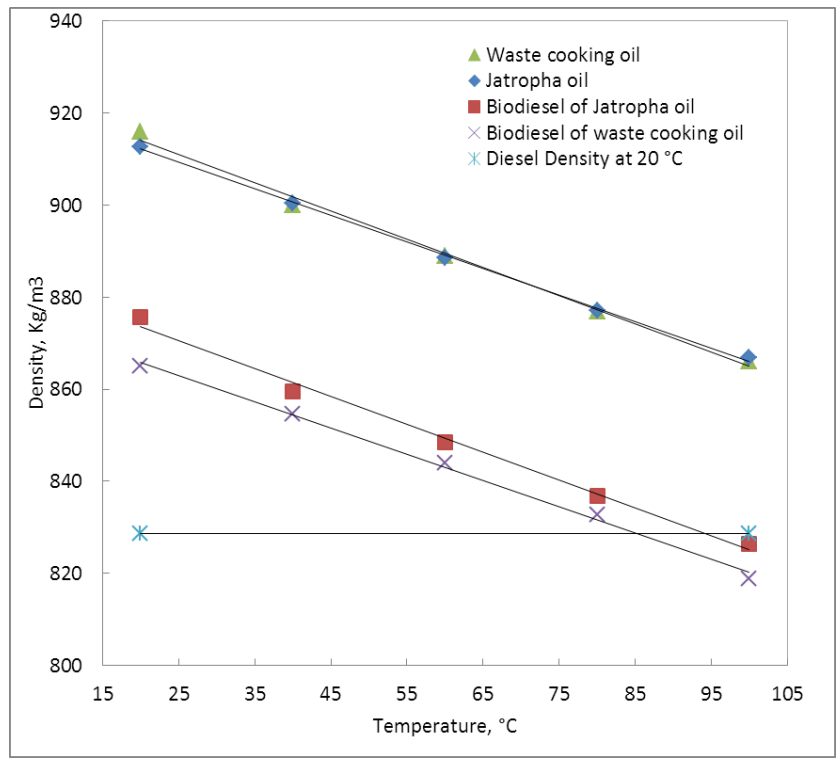

Fig. 4: Effect of temperature on oil density

\subsection{Effect Of Temperature On Oil Viscosity}

Figure 5 shows the variations in viscosities for different temperatures of oil and biodiesel. The results reveal that oil temperatures have significant effect on the viscosity of the extracted oils. The measured values of densities by test method ASTM D445 at the same temperature of $40^{\circ} \mathrm{C}$ for conventional diesel, jatropha bio-oil, jatropha biodiesel, waste cooking oil bio-oil, WCO biodiesel are 1.2, 4.1, 1.4, 4, and $1.509 \mathrm{CP}$, respectively. The viscosities of oils decrease with increase in temperature. The viscosity is inversely proportional to the oil temperature as a linear relationship as obtained by the measured results. Preheating of bio-oil fuel is one of the solutions to overcome the problems related to the higher oil viscosity in diesel engines. Correlations of viscosities at different temperatures are helpful in predicting and calculating viscosities as shown in Table 4. Viscosity correlations at different temperatures can predict and calculate viscosities for oil and biodiesel. 


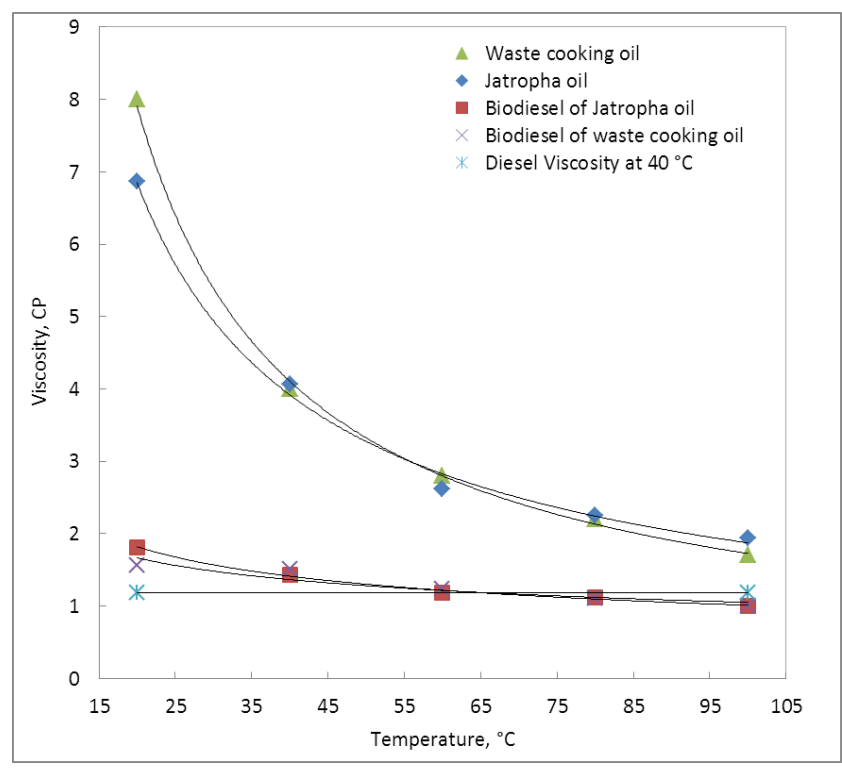

Fig. 5: Effect of temperature on oil viscosity

Table 4: Temperature and viscosity correlations for oil and biodiesel

\begin{tabular}{ccc}
\hline No. & Type & Viscosity Equations \\
\hline 1 & Jatropha oil & $\mu=76.562 \mathrm{~T}^{-0.806}$ \\
\hline 2 & Biodiesel of Jatropha oil & $\mu=5.4451 \mathrm{~T}^{-0.366}$ \\
\hline 3 & Waste cooking oil & $\mu=134.63 \mathrm{~T}^{-0.946}$ \\
\hline 4 & Biodiesel of waste cooking oil & $\mu=3.9265 \mathrm{~T}^{-0.286}$ \\
\hline
\end{tabular}

\subsection{Properties Of Bio-Oil And Biodiesel}

The measured properties of the tested fuels are presented in Table 5. The heating values of diesel, jatropha oil, jatropha biodiesel, waste cooking oil and, WCO biodiesel were 42000, 39128, 38789, 37713 , and $42948 \mathrm{~kJ} / \mathrm{kg}$, respectively. The fuel heating value determines the availability of heat to produce the engine power. Therefore, heating values are important in the choice of alternative fuels for diesel engines to increase the engine performance.

Cetane numbers for diesel, jatropha bio-oil, jatropha biodiesel, waste cooking oil bio-oil, and WCO biodiesel are 45, 37.83, 42.62, 150 and 65.19, respectively. Fuel combustion quality in engine was measured by Cetane number. Cetane number affects ignition quality and engine performance, cold starting, warm up, and engine combustion roughness .Shorter ignition delay causes higher Cetane number and leads to reduction in engine performance.

Flash points for of diesel, jatropha oil, jatropha biodiesel, waste cooking oil and, WCO biodiesel are 75, $142,121,167$, and $120^{\circ} \mathrm{C}$, respectively. The flash point is critical for storage safety and handling. Oil has higher flash temperature than biodiesel and ordinary diesel, so, storage and handling of oil are relatively less hazardous in comparison to diesel. 
Table 5: The measured properties of the tested fuels

\begin{tabular}{|c|c|c|c|c|c|}
\hline Properties & $\begin{array}{l}\text { Density at } 15.56 \\
{ }^{\circ} \mathrm{C}, \mathrm{kg} / \mathrm{m}^{3}\end{array}$ & $\begin{array}{l}\text { Kinematic Viscosity } \\
\text { at } 40^{\circ} \mathrm{C}, \mathrm{CP}\end{array}$ & $\begin{array}{l}\text { Flash } \\
\text { Point, }{ }^{\circ} \mathrm{C}\end{array}$ & $\begin{array}{l}\text { Lower Heating } \\
\text { Value kJ / kg }\end{array}$ & $\begin{array}{l}\text { Cetane } \\
\text { Number }\end{array}$ \\
\hline Method & $\begin{array}{l}\text { ASTM } \\
\text { D4052 }\end{array}$ & $\begin{array}{c}\text { ASTM } \\
\text { D445 }\end{array}$ & $\begin{array}{c}\text { ASTM } \\
\text { D93 }\end{array}$ & $\begin{array}{l}\text { ASTM } \\
\text { D-224 }\end{array}$ & $\begin{array}{c}\text { ASTM } \\
\text { D613 }\end{array}$ \\
\hline Diesel & 829 & 1.2 & 75 & 42000 & 45 \\
\hline Jatropha Oil & 913 & 4.1 & 142 & 39128 & 37.83 \\
\hline $\begin{array}{l}\text { Jatropha } \\
\text { Biodiesel }\end{array}$ & 876 & 1.4 & 121 & 38789 & 42.62 \\
\hline $\begin{array}{c}\text { Waste } \\
\text { cooking oil }\end{array}$ & 916 & 4 & 167 & 37713 & 150 \\
\hline $\begin{array}{c}\text { WCO } \\
\text { biodiesel }\end{array}$ & 865.01 & 1.509 & 120 & 42948 & 65.19 \\
\hline
\end{tabular}

\section{SUMMARY AND CONCLUSIONS}

The main goal of this paper is to compare jatropha oil extracted by screw press and oil produced from waste cooking oil to obtain biodiesel based on optimum physical and chemical properties. The present results led to these conclusions:

1. The screw press is the optimum examined technique (or is good) for large scale production of biooil and biodiesel from jatropha seeds. The oil extraction yield is up to $20 \%$ at $60 \mathrm{rpm}$ rotational speed and $100{ }^{\circ} \mathrm{C}$. It has the minimum extraction time because it is a continuous process.

2. The waste cooking oil has darker color which is caused by oxidation during the cooking process; it has Lovibond No. 10 and maximum FFA of $4.596 \%$. Jatropha oil extracted by screw press method gave the lighter oil color because of the lower FFA of 2.7\% and Lovibond No. 4 for the produced oil.

3. The present correlations in Tables 3 and 4 for viscosities and densities can be used to predict and calculate viscosities and densities at any given temperature for oil and biodiesel produced from jatropha and waste cooking oil. The extracted oil and biodiesel densities and viscosites decreased with increase in temperature.

4. Flash points of oil and biodiesel are higher than that of fossil diesel so, storage and handling of oil are relatively less hazardous in comparison to hydrocarbon diesel. The heating values of diesel, jatropha bio-oil, jatropha biodiesel, waste cooking oil bio-oil, and WCO biodiesel were 42000, $39128,38789,37713$, and $42948 \mathrm{~kJ} / \mathrm{kg}$, respectively.

5. The major fatty acids in jatropha oil were oleic, linoleic, palmitic, and stearic fatty acids, whereas for waste cooking oil were palmitic and oleic fatty acids. Jatropha oil can be classified as linoleicpalmitic oil compared to waste cooking oil bio-oil which is classified as Oleic-palmitic oil. Jatropha oil has higher linoleic fatty acid, and WCO oil has higher oleic fatty acid.

Finally, jatropha oil extracted by screw press method is the optimum process because it has a high yield of up to $20 \%$, good acceptable properties overall as compared to WCO oil. WCO biodiesel has good acceptable properties overall compared to jatropha biodiesel. Both jatropha oil, preheated to a temperature of $100{ }^{\circ} \mathrm{C}$, and WCO biodiesel, under a preheating temperature of $40{ }^{\circ} \mathrm{C}$, can be used as alternative fuels to conventional fossil diesel.

\section{REFERENCES}

[1] S.M.A. Ibrahim, K.A.A. Abed, M.S.S. Gad and H.M. Abu Hashish, Optimum oil yield from Egyptian Jatropha seeds using screw press, Int. J. Mech. Mechatronics Eng. 17 (2017), pp. 47-56.

[2] S. Raja, Biodiesel production from jatropha oil and its characterization, Res J Chem Sci, 2011.

[3] A.H.H. Tambunan, J.P.P. Situmorang, J.J.J. Silip, A. Joelianingsih and T. Araki, Yield and 
physicochemical properties of mechanically extracted crude Jatropha curcas L oil, Biomass and Bioenergy 43 (2012), pp. 12-17.

[4] M.Y. Koh, T.I. Mohd. Ghazi and T.I.M. Ghazi, A review of biodiesel production from Jatropha curcas L. oil, Renew. Sustain. Energy Rev. 15 (2011), pp. 2240-2251.

[5] S. Shah, A. Sharma and M.N. Gupta, Extraction of oil from Jatropha curcas L. seed kernels by enzyme assisted three phase partitioning, .

[6] S. Shah, A. Sharma, M.G.-B. Technology and U. 2005, Extraction of oil from Jatropha curcas L. seed kernels by combination of ultrasonication and aqueous enzymatic oil extraction, Elsevier 2015)), .

[7] A. Kumar, S.S.-I. crops and Products and U. 2008, An evaluation of multipurpose oil seed crop for industrial uses (Jatropha curcas L.): a review, Elsevier .

[8] P. Sirisomboon, P. Kitchaiya, T. Pholpho and W. Mahuttanyavanitch, Physical and mechanical properties of Jatropha curcas L. fruits, nuts and kernels, Biosyst. Eng. 97 (2007), pp. 201-207.

[9] A. Oyinlola, A. Ojo and L.O. Adekoya, Development of a laboratory model screw press for peanut oil expression, J. Food Eng. 64 (2004), pp. 221-227.

[10] A.M.A. Attia and A.E. Hassaneen, Influence of diesel fuel blended with biodiesel produced from waste cooking oil on diesel engine performance, Fuel 167 (2016), pp. 316-328.

[11] A. Chhetri, K. Watts and M. Islam, Waste Cooking Oil as an Alternate Feedstock for Biodiesel Production, Energies 1 (2008), pp. 3-18.

[12] Z. Helwani, M.R. Othman, N. Aziz, W.J.N. Fernando and J. Kim, Technologies for production of biodiesel focusing on green catalytic techniques: A review, Fuel Process. Technol. 90 (2009), pp. 1502-1514.

[13] M. Balat, Potential alternatives to edible oils for biodiesel production - A review of current work, Energy Convers. Manag. 52 (2011), pp. 1479-1492.

[14] A. Sanjid, H.H. Masjuki, M.A. Kalam, S.M.A. Rahman, M.J. Abedin and S.M. Palash, Production of palm and jatropha based biodiesel and investigation of palm-jatropha combined blend properties, performance, exhaust emission and noise in an unmodified diesel engine, J. Clean. Prod. 65 (2014), pp. 295-303.

[15] M. Canakci, The potential of restaurant waste lipids as biodiesel feedstocks, Bioresour. Technol. 98 (2007), pp. 183-190.

[16] A. Khalid, N. Azman, H. Zakaria, B. Manshoor, I. Bin Zaman, A. Sapit et al., Effects of storage duration on biodiesel properties derived from waste cooking oil, in Applied Mechanics and Materials, 554 (2014), pp. 494-499.

[17] A review on novel processes of biodiesel production from waste cooking oil. Elsevier Ltd, 2013.

[18] A. Demirbas, Biodiesel Alternative, A Realistic Fuel Engines, for Diesel, Springer-Verlag London Ltd. 10 (2008), pp. 971-978.

[19] A.E.A.E. Atabani, A.S. Silitonga, H.C.H.C.H.C. Ong, T.M.I.I. Mahlia, H.H. Masjuki, I.A. Badruddin et al., Non-edible vegetable oils: A critical evaluation of oil extraction, fatty acid compositions, biodiesel production, characteristics, engine performance and emissions production, Renew. Sustain. Energy Rev. 18 (2013), pp. 211-245.

[20] S. Jain and M.P. Sharma, Biodiesel production from Jatropha curcas oil, Renew. Sustain. Energy Rev. 14 (2010), pp. 3140-3147.

[21] P. Nakpong and S. Wootthikanokkhan, Roselle (Hibiscus sabdariffa L.) oil as an alternative feedstock for biodiesel production in Thailand, Fuel 89 (2010), pp. 1806-1811.

[22] [E. Ankapong, The Influence of Physicochemical Characteristics of Vegetable Oils on ohe Quality of Biodiesel Produced from Palm Oil, Palm Kernel Oil, Refined Soyabean Oil, Unrefined Soyabean Oil and Jatropha Curcas Oil., Kwame Nkrumah University of Science and Technology, 2010.

[23] S. Bojan and S. Durairaj, Producing biodiesel from high free fatty acid Jatropha curcas oil by a two step method-an Indian case study, J. Sustain. Energy Environ. 2012.

[24] A. Kumar Tiwari, A. Kumar and H. Raheman, Biodiesel production from jatropha oil (Jatropha curcas) with high free fatty acids: An optimized process, Biomass and Bioenergy 31 (2007), pp. 569-575. 
COMPARISON OF DIFFERENT METHODS FOR PRODUCING BIODIESEL FROM EGYPTIAN JATROPHA SEEDS AND LOCAL WASTE COOKING OIL

[25] G.G. Kombe, A.K. Temu, H.M. Rajabu and G.D. Mrema, High Free Fatty Acid (FFA) Feedstock Pre-Treatment Method for Biodiesel Production, in Second International Conference on Advances in Engineering and Technology, 2012, pp. 182. 